\title{
Farm-Boarding School Management: Linear Programming Contributions in the Search of Self-Sufficiency and Optimization
}

\author{
Carina Simionato de Barros ${ }^{1}$, Gabriela Geraldi Mendonça ${ }^{1}$ \& Augusto Hauber Gameiro ${ }^{1}$ \\ ${ }^{1}$ School of Veterinary and Animal Science, University of Sao Paulo, Pirassununga, Sao Paulo, Brazil \\ Correspondence: Augusto Hauber Gameiro, School of Veterinary and Animal Science, University of Sao Paulo, \\ Pirassununga, SP, Brazil. Tel: 55-19-3565-4224. E-mail: gameiro@usp.br
}

Received: December 19, 2016

Accepted: January 14, 2017 Online Published: February 15, 2017

doi:10.5539/jas.v9n3p59

URL: http://dx.doi.org/10.5539/jas.v9n3p59

\begin{abstract}
Farm schools offer a learning environment for the education of students in Agricultural Technical Programs and offer this program adopting boarding systems ("farm-boarding schools" or "FBS"). The big challenge in FBS is balancing education and production, that is, provide resources for practical classes and at the same time provide food for farm residents from a pre-defined budget by the sponsoring institution. The aim of this paper is to present a linear programming model to plan and optimize FBS production and supply. The model was applied in two FBS in Brazil. The model developed could show the complexity of the FBS system, which features a variety of productions and the interactions among them. The modeling process presented positive results from a technical and managerial point of view, including people management. The formulated model showed an optimized scenario which extended the managers' analysis horizon and allowed safer decision making. The system's complexity hampers dialogue between the farm-boarding school team and managers. From the modeling process and the standardization of data and generated results, there was a greater safety margin to present investment proposals and analyzes, accelerating the decision-making process, which was a positive addition to the system.
\end{abstract}

Keywords: agribusiness, modelling process, operational research, production cost, reducing costs

\section{Introduction}

Farm schools have been established in Brazil to offer a learning environment for the education of students in Agricultural Technical Programs which would provide them "learning to do by doing" activities (Franco, 1994). The school needs to offer diversified cattle-raising, agricultural and agro-industrial (food processing) activities for the teaching and learning processes. Mont'alvão (2008) says that the farm-school should be a specific laboratory for the development of agricultural practices where theoretical and practical knowledge will be developed through agricultural, agroindustrial and zootechnical projects, seeking a balance between theory and practice.

In Brazil, several farm schools which offer this program adopt boarding systems, thus also fulfilling a social role. In this study, these institutions will be called "farm-boarding schools" or "FBS". Goffman (1974) defines a boarding school as a place of residence and work housing several individuals in a similar situation, separated from outside society for a considerable period in a relatively closed and formally ruled life. This system has prevailed for many years in Brazil in professional agricultural education, catering to low-income rural populations by providing educational opportunities, residence, meals, medical and dental care, clothing and other goods and services (Conceição, 2010). This system is still operational in both public and private institutions, offering rural area youth a real change of becoming agribusiness professionals. In addition to boarding students, workers also live on the farms with their families in these institutions, since these are far from major urban centers and there is limited daily transportation available. The location of these farm-boarding schools restricts the purchase of goods on the market so that the farms need to be self-sufficient in food production.

The big challenge in FBS is balancing education and production, that is, provide resources for practical classes and at the same time provide food for farm residents from a pre-defined budget by the sponsoring institution. One of the shortcomings of these institutions is the difficulty in managing resources and providing better learning conditions for students, in addition to the fact that the activities are not primarily intended to make a profit (Marques \& Love, 1993). Thus, the problem faced by the managing institution is rather complex, as there 
are many variables and restrictions to be considered. Moreover, there is a need for multiple responses related to various choices as to what, how and when to grow each different crop and livestock. These activities are directly affected by each other, and demand a comprehensive global analysis so that the best choices are made. For this to come true there is the need for qualified professionals, who in turn will need helping tools in the decision-making process. In this scenario, there are FBS that have no support to use resources efficiently. Also, studies focusing on the management of these institutions are scarce, and specific management tools for these cases are often unavailable.

The aim of this paper is to present a linear programming model to plan and optimize FBS production and supply. The use of LP in agricultural planning has been consolidated in literature, but this study sought to innovate by inserting technique into a broader production and activity system which considers, besides the traditional technical agricultural issues, the social and pedagogical role of these institutions. In addition to the model proposition, this paper reports its implementation and improvement processes as a management tool in two FBS. Basically, the model seeks to define the combination of agricultural, livestock and agro-industrial activities more efficiently to meet the educational (classes) and productive (food) demand for the FBS system maintenance with minimal cost.

\section{Method}

\subsection{Managing Farm-Boarding School Issues}

The main purpose of this system is to provide educational activities, especially practical classes, geared to professional qualification processes for students to enter the labor market, since agriculture enables the professional to work in livestock, crop and agro-industrial production, as well as management. To meet this pedagogical demand, one must deal with the managerial complexity of making different resources compatible with the school calendar, allowing the student as much experience with production processes as possible. Another goal of FBS is to provide the local population (students and staff) with daily meals. As food production occurs while students are attending classes, this production supplies the so-called internal "Food Sector", which is supplied either by local production or market purchase. The sale of farm products to obtain profits is unusual because most institutions are charities (non-profit entities, as required by Brazilian law). Therefore, in most cases there should be no surplus production except for that consumed by the FBS community, which makes it a more complex issue, since the manager must make the decision to buy or produce according to available resources, minimize costs and not produce beyond consumption capacity, nor aim to obtain financial gains.

The "Livestock and Agricultural Sectors" offers products to the farm's "Food Sector", composed by the food processing unity (vegetable and animal product processing) and by the farm's canteen. The staff provides workforce for the different sectors, and students interact with the Agricultural, Livestock and Processing sectors, which provide a learning environment. The sectors are supplied by the market when there is no possibility of local production. However, due to purchase difficulties because the remote location far from urban centers, as well as food distribution difficulties, these FBS are required to maximize self-sufficiency within their premises and, in order to attain that goal, it is necessary to use available resources (land, labor and capital goods) efficiently.

Students and staff live on the farm in an urbanized area that offers housing and recreational facilities. This area needs constant maintenance, so that it competes with the agricultural sector for services and resources. Property maintenance services require logistics support (tractors and implements), and maintenance of internal roads require mechanized work, in addition to landscaping and gardening. Thus, the use of resources (labor, inputs and machinery) must be compatible with the productive (Agricultural and Livestock), consumer (Food), teaching (the school itself) and urbanized area (housing and recreational facilities) sectors. Given these multiple and correlated activities, the management team faces planning difficulties, and several internal conflicts between productive (Livestock and Agricultural) and consumer (Food) sectors arise, since production does not always meet demand, which needs to be partly supplied by the market. Another aspect that must be emphasized is that, on behalf of students' learning, there may be agricultural production that would not otherwise be viable from a commercial point of view, since this food could be purchased at lower prices on the market. In other words, there is not necessarily full production efficiency, since students are doing and learning, and require several hours of monitoring from the technician responsible for the sector (hours that are not intended for production itself, but rather for student's guidance); thus, they spend more time than usual on a given activity, which often demands more inputs (waste, mistakes), so productivity may be lower than expected. Therefore, a system with an identical performance to that of a commercial farm cannot be expected. A comparative analysis between a traditional farm and an FBS reveals that the latter is more complex (Table 1). 
Table 1. Comparative analysis between a traditional farm and a FBS

\begin{tabular}{|c|c|c|}
\hline & Traditional farm & Farm-boarding school \\
\hline Major goal & Maximize profit & Promote teaching and learning activities at minimal costs \\
\hline Planning logistics & $\begin{array}{l}\text { Select profitable agricultural and } \\
\text { livestock activities } \\
\text { Meet market demands }\end{array}$ & $\begin{array}{l}\text { Select diversified agricultural and agribusiness activities } \\
\text { that favor students' training in the first place and feed } \\
\text { community } \\
\text { Plan production in accordance with school calendar } \\
\text { Keep an urbanized area on the farm }\end{array}$ \\
\hline Production logistics & $\begin{array}{l}\text { Produce in an efficient and economically } \\
\text { viable way }\end{array}$ & $\begin{array}{l}\text { Produce for students to learn, even if this requires } \\
\text { economically unviable activities or less technical } \\
\text { efficiency as compared to regional results } \\
\text { Produce for domestic consumption }\end{array}$ \\
\hline Marketing logistics & Sell production profitably & $\begin{array}{l}\text { Not the purpose of the system } \\
\text { Eventual sales without seeking profit }\end{array}$ \\
\hline Supply logistics & $\begin{array}{l}\text { Buy on the market inputs needed to } \\
\text { supply the production process }\end{array}$ & $\begin{array}{l}\text { Maximize self-sufficiency, especially of highly perishable } \\
\text { products }\end{array}$ \\
\hline Restrictions & Economic and environmental techniques & $\begin{array}{l}\text { Economic, environmental and educational techniques } \\
\text { Urbanized area services }\end{array}$ \\
\hline Role of employees & $\begin{array}{l}\text { Provide workforce for the production } \\
\text { process }\end{array}$ & $\begin{array}{l}\text { Provide workforce for the production process and invest in } \\
\text { the students' learning process }\end{array}$ \\
\hline Role of system for workers & $\begin{array}{l}\text { Reward work (salary) and eventually } \\
\text { provide housing }\end{array}$ & $\begin{array}{l}\text { Reward work (salary) } \\
\text { Provide housing and daily meals } \\
\text { Provide jobs, health and education for all family members } \\
\text { ensuring their inclusion in the system }\end{array}$ \\
\hline Destination of production & Sale to generate income & Use within the system without production sale \\
\hline Income & $\begin{array}{l}\text { Obtained from the sale of goods produced } \\
\text { in the system }\end{array}$ & Supplied by a sponsoring institution \\
\hline
\end{tabular}

\subsection{Canuanã FBS Characterization}

Canuanã Farm Boarding School occupies 2,549 hectares and is located in Formoso de Araguaia county in the State of Tocantins, Brazil. There is an urbanized area on the farm in which there are classes and the population resides, as well as a rural area where farming activities are developed by the Agricultural and Livestock Sector. The Food Sector processes food for consumption. Two-hundred employees and 909 students live in the school, 270 of whom are enrolled in the Agriculture Technical Program.

The livestock Sector includes a beef cattle herd of 220 registered Nellore animals ("elite herd") and 1,131 Nellore cattle from F1 crossings with European breeds ("commercial herd"), raised in 1,450 hectares of pasture. The horse troop consists of 25 animals. The dairy cattle herd consists of 285 animals of Gir/Holstein and Dairy Gir breeds. Lactating cows are raised in both: conventional and intensive systems. In the conventional system, they remain on the pasture during the rainy season and are given sorghum silage in the trough during the dry season. In the intensive system, they are kept in rotational grazing on irrigated paddocks. Sheep farming consists of 61 beef sheep raised on pasture and supplemented when necessary. Pig farming includes 14 sows. Also, two flocks of 10,000 broilers are raised every year. Throughout the year there are 500 laying hens in production. Beekeeping is maintained by 12 beehives.

The agricultural sector consists of annual crops planted each cropping season which includes corn (68.4 ha), rice (10 ha) and sorghum (43.2 ha) for silage. Horticulture includes 30 different crops in $915 \mathrm{~m}^{2}$, and fruit trees consist of 17 different crops in 7.1 hectares.

The Food Sector offers breakfast, lunch, dinner and two snacks for all students and staff daily. The food processing unity produces cheese, pasteurized milk, yogurt and candies. Food purchase only occurs exceptionally, since the farm is located far from suppliers. To purchase fruit and vegetables, a $370 \mathrm{~km}$ drive in hot weather is required, a distance which prevents the purchase of leafy vegetables. As for the agricultural sector workforce, there are two coordinators for a team of 28 workers. The Agricultural Sector team performs services 
in the urbanized area (gardening, garbage collection, transportation and logistics support to the Food Sector), therefore competing with crops for resources.

\subsection{Bodoquena FBS Characterization}

Bodoquena School occupies 775 hectares and is located in Miranda county the state of Mato Grosso do Sul, Brazil. It is like Canuanã FBS, having the same sector structure, an urbanized area and study availability. The main difference from the first school is in the fact that, out of the 900 students and 190 employees, only 650 reside locally, the others only staying for the class or work period.

The Livestock Sector includes a herd of beef cattle of 981 Nellore and F1 crossings with European breeds raised in 500 hectares of pasture. The horse troop consists of 19 animals. The dairy cattle herd consists of 330 animals of Gir/Holstein and Dairy Gir breeds raised on pasture and supplemented with purchased corn silage (there is no local production) and concentrated feed. Sheep farming includes 21 beef sheep raised on pasture throughout the year. Pig farming includes 13 sows. The farm also raises a flock of 1,000 broilers every year, and there are 500 laying hens in production annually. Beekeeping is maintained by 20 beehives.

There are no crops of cereals, grain or forage for silage in the Agricultural Sector. Horticulture includes the cultivation of 30 different crops in 15 hectares, and fruit trees consist of nine different varieties in 15 hectares.

The Food Sector offers lunch and two snacks for all students and staff daily, and those living on the farm are also served breakfast and dinner. Market access for the purchase of goods is easier than that on Canuanã, and a shorter $60 \mathrm{~km}$ trip is necessary to purchase supplies; however, the purchase of leafy vegetables is equally impossible due to high temperature conditions.

As for the workforce, there are two coordinators for a team of 20 employees in the Agricultural Sector.

\subsection{Model Description}

The "FBS Planning, Production Optimization and Supply Model" (FBS-PPOSM) is a system that provides guidance as to the number of animals, area to be cultivated and agro-industrial production, thus minimizing total costs and providing a suitable environment for the teaching-learning process to take place. The FBS-PPOSM is based on monthly intervals, totaling 36 months. The mathematical structure was coded and processed by the 22.5 version General Algebraic Modeling System software (GAMS), and CPLEX 10.1 was used as solver.

\subsubsection{Model Data}

The main data that feed the model are listed as follows, divided into groups: i) Land: land areas classified according to type of occupation (urbanized, pasture, garden, crops, vegetable garden and orchard) and period (dry or rainy); ii) Animal output: animal category, herd composition, fertility, mortality, productivity, weight, land occupation, workforce and agricultural machinery demand, slaughter age, production months, nutritional requirements, variable costs, purchase and sale prices; iii) Vegetable output: annual crops, vegetable garden crops, orchard crops, leafy vegetable hydroponics, types of pasture, silage production, dry matter production, productivity, variable costs, workforce and agricultural machinery demand, month of land occupation, planting season, harvesting costs, and gardening; iv) Agro-industrial output (food processing): milk conversion into dairy products, carcass conversion into meat, fruit conversion into candies, variable costs, workforce demand; v) Animal feed: type, price and nutritional composition; vi) Human population food: type, price and nutritional categories; vii) Human population meals: type (breakfast, lunch, dinner, snack), number, amount of food per meal and dietary variability (number of days each food is offered in one month); viii) Stocks: animal feed, human population food and production inputs; ix) Farm equipment: type, availability in hours and fuel consumption; $x$ ) Workforce: number of employees and hours worked; xi) Class resources: minimum number of animals, crops and agro-industrial products, months in which resource is needed and hours required for students' practice; xii) Population: number of inhabitants, number of students and number of employees; xiii) Fixed costs: salaries; and xiv) Other (fixed) costs: depreciation and electricity.

\subsection{Objective Function and Decisive Variables}

\subsubsection{Variables}

The model variables are: $\mathrm{C}$ : total cost (R\$); $X A P_{a t}$ : number of animals a in production in period $t$ (per animal); $X A M_{a t}$ : number of animals a purchased in period $t$ (animal); $X A V_{a t}$ : number of animals a sold in period $\mathrm{t}$ (per animal); $X C P_{c t}$ : area of vegetable cultivation $c$ produced in period $t\left(\mathrm{~m}^{2}\right) ; X J P_{j, t}:$ garden area $j$ used in period $t$ $\left(\mathrm{m}^{2}\right) ; X H M_{h t}$ : amount of human food $h$ purchased in period $t(\mathrm{~kg}) ; X H P_{h t}$ : amount of human food $h$ for produced in period $t(\mathrm{~kg}) ; X H C_{h t}$ : amount of food $h$ eaten in period $t(\mathrm{~kg}) ; X H E_{h t}$ : amount of human food $h$ stored in period $t$; $X H R_{h t}$ : amount of human food $h$ to be processed in period $t(\mathrm{~kg}) ; X H D_{h t}$ : amount of human food $h$ for 
pedagogical practices in period $t(\mathrm{~kg}) ; X G P_{g t}$ : amount of animal feed $g$ produced in period $t(\mathrm{~kg}) ; X G M_{g t}$ : amount of animal feed $g$ purchased in period $t(\mathrm{~kg}) ; X G E_{g t}$ : amount of animal feed $g$ stocked in period $t(\mathrm{~kg}) ; X G C_{g a t}$. amount of animal feed $g$ eaten by animal $a$ in period $t(\mathrm{~kg}) ; X O M_{t}$ : amount of diesel oil purchased in period $t$ (liter).

\subsubsection{Parameters}

The model parameters are: $c v a_{a}$ : variable costs of animal $a$ production (R $\$ /$ head); prc $a t$ : animal $a$ purchase market price in period $t\left(\mathrm{R} \$ /\right.$ head); $\operatorname{prg}_{g t}$ : market price for purchase of animal feed $g$ in period $t$ (R\$/weight unit); $c v c_{c}$ : variable production costs of vegetable cultivation $c(\mathrm{R} \$ /$ hectare $) ; c v j_{j}$ : variable costs of gardening activity $j$ $(\mathrm{R} \$ / \mathrm{m} 2) ; p r h_{h t}$ : market purchase price of human food $h$ in period $t(\mathrm{R} \$ /$ weight unit); pro $t$ : market price for diesel fuel purchase in period $t$ (R\$/liter); cfm: workers' payroll fixed monthly costs (R\$); cfo: other fixed monthly costs $(\mathrm{R} \$)$.

\subsubsection{Objective Function}

The objective function shown below represents total costs to be minimized obtained by the sum of the variable costs of animals, livestock costs, animal feed purchase costs, vegetable production variable costs, gardening variable costs, school population food purchase costs, fuel costs, fixed costs, and employee (labor) costs:

$$
\begin{aligned}
\operatorname{MinC}= & \sum_{a, t} c v a_{a} X A P_{a t}+\sum_{a, t} \operatorname{prc}_{a t} X A M_{a t}+\sum_{g, t} \operatorname{prg}_{g t} X G M_{g t}+\sum_{c, t} c v c_{c} X C P_{c t} \\
& +\sum_{j, t} c v j_{j} X J P_{j t}+\sum_{h, t} \operatorname{prh}_{h t} X H M_{h t}+\sum_{t} \operatorname{pro}_{t} X O M_{t}+c f m+c f o
\end{aligned}
$$

The main constraints to the model are related to the different sectors.

Livestock Sector: herd composition, herd stability maintenance, impossibility of breeding at certain periods, herd maintenance for pedagogical practices, use of area available, food stock inventory, food storage capacity, initial food stock, supply of mineral nutritional needs, balance between roughage and concentrated feed for herbivores, animal-origin human food production (meat, eggs, honey) and raw milk production.

Agricultural Sector: plant cultivation area use dynamics, impossibility of plant cultivation at certain periods, maintenance of plant crops for pedagogical practices, plant feed production for animals, food production for humans (fruit, vegetables, cereals).

Food and Food Processing Sector: Dairy product and fruit processing. Canteen: food stock balance, food production for teaching practice maintenance, storage capacity limit, initial stock, daily meal servings, food diversification at meals.

Resource availability: livestock, agricultural and agro-industrial sector work, machinery hours for livestock and agriculture sectors, diesel oil consumption by livestock and agriculture sectors, arable land and pasture area availability.

\subsection{Scenarios}

The six following scenarios were built: i) 1C: Canuanã-based scenario, representing a farm-school reality restricted by parameters showing reality prior to optimization; ii) $2 \mathrm{C}$ : optimal solution (cost minimization) in Canuanã as appointed by model; iii) 3C: optimal solution (cost minimization) in Canuanã after effective implementation of changes suggested by scenario 2C; iv) 1B: Bodoquena-based scenario representing farm-school reality restricted by parameters showing reality prior to optimization; v) 2B: optimal solution (cost minimization) on Bodoquena as appointed by model; vi) 3B: optimal solution (cost minimization) on Bodoquena after effective implementation of changes suggested by Scenario $2 \mathrm{~B}$.

\subsection{Model Construction Background}

The first step in the construction of the model was making up a multidisciplinary team at FBS Canuanã to collect the necessary data: survey of area, inputs, costs, productivity, class resources, workforce, machine hours, and identification of major conflicts and difficulties to be overcome. The team consisted of the school advisor, five teachers, a veterinarian, an agronomist, a nutritionist and eight agriculture technicians, totaling 15 professionals who worked under the supervision of the authors. Meetings and training sessions for data collection were carried out between 2010 and 2013. A questionnaire was devised to be answered by teachers as to area, animal, plant variety and agro-industrial input needs to set a minimum standard for school practical activities, which is a fundamental constraint of the model, once the school comes first in the system. Meanwhile a model was formulated and restrictions forcing animal and crop area production to represent the base scenario were established (1C). Later these restrictions were relaxed and Scenario $2 \mathrm{C}$ was created. The model was validated 
together with the Canuanã team at a face to face meeting. The results were presented to institution sponsors in late 2013, which made decisions based on the scenarios presented which were later implemented in 2014. Results of these actions were achieved in 2015.

One of the decisions was to implement the model as a management tool on Bodoquena throughout 2014. For that purpose, the same process of training Canuanã professionals by the research team was followed. Improvements were identified along this process, and the Bodoquena team suggested the addition of items that could be useful because of context particularities. Thus, the redesigned model was validated by the two teams. The scenarios were then presented to institution sponsors and practical actions to be undertaken were defined, similarly to Canuanã.

\section{Results}

\subsection{Of the Modeling Process, as a Whole}

The model developed could show the complexity of the FBS system, which features a variety of productions and the interactions among them. The modeling process presented positive results from a technical and managerial point of view, including people management.

The usual division of the system into sectors focuses only on the results and processes of each sector, without considering a wider view. As a mapping of flows and a survey of the interactions between sectors was performed, staff integration was improved, and each sector could realize the demand for labor, production capacity and restrictions of the other, thus facilitating communication and process understanding.

A greater dialog between system managers and the sponsoring institution to meet the demand for investments and improvements based on the generated scenarios, as well as to abandon inefficient practices, was evidenced. Estimated results by the model provided safer decision-making, speeding up processes that used to take longer to analyze.

The modeling process presented qualitative gains for the team, directly contributing to greater system efficiency. Besides, it pointed out activities that needed improvement. All activities recommended to be excluded from the model were thoroughly discussed by the technical team to identify reasons and assess viability in case some coefficients were altered.

\subsection{Canuanã Implementation and Decision Making after Scenario Analysis}

The comparison between system annual costs in Scenarios $1 \mathrm{C}$ and $2 \mathrm{C}$ revealed a potential reduction of $26.5 \%$ because of the reallocation of productive resources. Based on Scenario $3 \mathrm{C}$ results, a $12.4 \%$ total reduction of system costs was obtained, as compared to Scenario $1 \mathrm{C}$.

Although the number of animals in the herd was changed, the minimum necessary to ensure pedagogical practices would be guaranteed, which is a model asset, once it must first provide resources for lessons.

There was an indication for an increase in the beef cattle commercial herd in Scenario 2C (Table 2), which would compensate for the reduction in the herd elite, as both are destined for meat production. The $81.8 \%$ reduction in beef seedstock cattle in $2 \mathrm{C}$ can be explained by the fact that these animals have higher production costs and by the absence of a structured profit-generating commercial process. This herd is only kept because of a pedagogical restriction demanding their maintenance for classes. From the analysis of Scenario $2 \mathrm{C}$ results, the management team chose to adopt the strategy pointed out by the model. Thirty-five cows to make up the seedstock herd were selected, and the remaining ones were transferred to the commercial herd, thus improving their genetics. Amimal management and pasture improvements were made in the commercial herd so that a $20 \%$ increase in pregnancy rate and a 3\% heavier carcass have already been obtained (Scenario 3C). The number of horses and mules in $2 \mathrm{C}$ increased because of the larger number of cattle, since there is a relationship between these animals. An $8 \%$ troop increase to meet the demand for cattle raising labor and practical classes was obtained (3C). 
Table 2. Number of livestock and beehive units in different scenarios

\begin{tabular}{llllll}
\hline Livestock & Scenario 1C & Scenario 2C & 1C/2C Variation (\%) & Scenario 3C & 2C/3C Variation (\%) \\
\hline Beef cattle: commercial & 1,131 & 1,376 & +21.7 & 1,316 & -4.4 \\
Beef cattle: genetic stock & 220 & 40 & -81.8 & 55 & +37.5 \\
Horses and mules & 25 & 27 & +8.0 & 27 & 0.0 \\
Dairy cattle: total herd & 285 & 88 & -69.1 & 219 & +148.9 \\
Dairy cattle: lactating cows & 68 & 40 & -41.1 & 56 & +40.0 \\
Sheep & 61 & 81 & +32.8 & 100 & +23.5 \\
Swine & 12 & 10 & -16.6 & 20 & +100.0 \\
Broilers & $2 \times 10,000$ & $2 \times 1,000$ & -90.0 & $1 \times 1,000$ & 0.0 \\
Laying hens in production & 350 & 200 & -42.8 & 442 & +121.0 \\
Beehives & 12 & 15 & +25.0 & 15 & 0.0 \\
\hline
\end{tabular}

Note. Scenario 1C: base Scenario; Scenario 2C: optimal solution; and Scenario 3C: one year after decision making.

The dairy cattle herd showed a high reduction in Scenario 2C (69.1\%). The number of lactating cows changed from 68 animals in Scenario 1C, 48 of which raised in an extensive system to ony 40, which were kept exclusively in an intensive system because production was higher as compared to the extensive system (15 vs. 7 liters of milk/day). This change impacted milk delivery for processing, whose analysis will be presented later. After Scenario $2 \mathrm{C}$ analysis, a reduction in the number of dry cows representing production costs without revenue was proposed. Also, the fact that Scenario 2C only shows intensive system production is noteworthy, revealing that investment in irrigated pasture can be compensated by increased productivity, which led managers to opt for a gradual transition to an intensive system. Scenario 3C already includes the implementation of irrigated pasture and 56 lactating cows are in this area, without milk delivery reduction to processing. Work towards greater productivity per cow was done, and within a year milk production increased from 8.2 to $11.2 \mathrm{~L} / \mathrm{cow} / \mathrm{day}$. This average is lower than the $15 \mathrm{~L} / \mathrm{cow} /$ day from the intensive system model, since in the former system (1C), only genetically superior animals remained in the intensive system, whereas currently all animals are kept in system (3C). The tendency over the years has been to select animals aiming to increase productivity.

Sheep farming in Scenario 2C should be reduced to 81 animals. Originally there were 100 animals in the herd, once birth and pregnancy rates increased with improved management.

The number of pigs should have a $14.3 \%$ reduction in Scenario 2C, which means a change from 14 to 12 matrices. The managers chose to keep 14 dams as a safety margin to ensure that $100 \%$ of pork was produced in the system. However, there were some specific situations that caused $3 \mathrm{C}$ to present a higher number of dams due to low fertility rates and increased piglet mortality. Efforts are being made to improve swine production rates and reduce the number of dams without reducing the availability of meat for consumption in the system.

Poultry farming, either broilers or laying hens, would only be maintained in Scenario 2C due to practical class restrictions. The management team chose to raise only a single hen flock for classes and as to egg production, improvements in the production process were determined so that it would become a viable activity and there would be no need to buy the product on the market. Currently the demand for eggs is being met without purchase (3C). As to beekeeping, there was a recommendation for 15 beehives in Scenario $2 \mathrm{C}$, the maximum possible number in the system, which was implemented (3C).

With animal husbandry reduction, there would be greater livestock workforce availability from the Livestock Sector. In Scenario 1C, 30.6\% of the workforce is destined to livestock; on the other hand, in Scenario 2C, this percentage would be reduced to $25.1 \%$ with herd reduction. The herd number optimal solution would imply restructuring the Livestock Sector and relocating employees to different activities. However, in practice this was not the case in $3 \mathrm{C}$ because hen egg production was not reduced and there was an increase of sheep and pig farming.

As to crop production, the increase in corn and forage corn area can be explained by an improved animal diet provided by calculations based on nutritional requirements (Table 3). In Scenario 2C, corn planting is suggested to meet the demand; however, farm managers decided that the technical team should estimate corn costs and market price annually to determine the plantation area, since there can be variations. As they could buy corn at a low price in 2014, just enough to meet demand was cultivated (3C). Scenario 2C suggests corn silage rather than 
sorghum production; however, sorghum was produced in $3 \mathrm{C}$ because there were seeds available from the previous crop. The intention was to evaluate corn silage productivity only. An integrated livestock-crop system is being implanted, with expectations of increased productivity and system optimization, as shown by several researchers (Gameiro et al., 2016; Peyraud et al., 2014; Bell et al., 2014). Lactating cows are the greatest consumers of this food, and in Scenario $2 \mathrm{C}$ they would be raised in an irrigated pasture system and thus get less supplementation, with part of the silage directed to beef cattle.

Table 3. Vegetable Crops and plantation areas in different scenarios

\begin{tabular}{llllll}
\hline Crop & Scenario 1C & Scenario 2C & $1 \mathrm{C} / 2 \mathrm{C}$ Variation (\%) & Scenario 3C & 2C/3C Variation (\%) \\
\hline Corn (ha) & 68.4 & 75.9 & +11.0 & 40.0 & -47.3 \\
Forage sorghum (ha) & 43.2 & 0 & -100.0 & 19.67 & - \\
Forage corn (ha) & 0 & 81 & +81.0 & 44.68 & -44.8 \\
Rice (ha) & 10.0 & 9.7 & -3.0 & 0.5 & -94.8 \\
Produce $\left(\mathrm{m}^{2}\right)$ & 915 & 643 & -29.7 & 945.0 & +47.0 \\
Fruit $\left(\mathrm{m}^{2}\right)$ & 72,000 & 73,000 & +1.4 & 73,000 & 0.0 \\
Garden (m $\left.{ }^{2}\right)$ & 500 & 500 & 0.0 & 500 & 0.0 \\
Cultivated pasture (ha) & 1,411 & 1,280 & -9.3 & 1,280 & 0.0 \\
Irrigated pasture (ha) & 2.2 & 4.1 & +86.4 & 10.0 & +143.9 \\
\hline
\end{tabular}

Note. Scenario 1C: base Scenario; Scenario 2C: optimal solution; and Scenario 3C: one year after decision making.

In the case of rice, despite $2 \mathrm{C}$ recommendation not to discontinue the crop, the management team chose to produce it only for classes $(3 \mathrm{C})$ because the product offered the same quality as that purchased on the local market. So, the discontinuation of the rice crop was decided.

The vegetable garden area in Scenario $1 \mathrm{C}$ was $915 \mathrm{~m}^{2}$ and should be reduced in $2 \mathrm{C}$, since the orchard area would be slightly increased. However, the technical team could obtain better management, implemented an irrigation system and improved productivity, resulting in an area increase in 3C.

The garden area remained unchanged in the different scenarios, and only generates costs without productivity because of its ornamental and educational nature, keeping only a minimum area on account of pedagogical restrictions. This area competes for both labor and machinery with farming.

As for pastures, the area was supposed to be slightly reduced because of including silage in cattle diet. There would be an increase in irrigated pasture so that all lactating cows would be kept in an intensive system using roughage feed exclusively. In practice, $3 \mathrm{C}$ has a larger area because the number of cows in it is higher than that recommended for $2 \mathrm{C}$.

The dairy processing in scenario $2 \mathrm{C}$ would not alter the amount of pasteurized milk for community consumption $(7,332 \mathrm{~L} /$ month) and dairy production, except for cheese, whose production would be discontinued and it would be purchased instead. Rather than accepting this scenario, the team decided to improve cow productivity and thus its production became viable in $3 \mathrm{C}$.

Regarding the workforce, the farm-boarding school keeps a fixed number of workers with no intention of change. In agriculture, a $100 \%$ labor occupation is reached only a few months per year upon planting and harvesting activities of annual crops. In the remaining months, the workers do not take up $100 \%$ of their time and this can be explained by model restrictions that demand maintenance of a fixed number of animals per category. If this restriction was not imposed, the purchase of livestock or increase in vegetable garden areas during periods of lower labor occupancy could have been recommended. Another option to increase occupation would be hiring temporary labor at annual crop planting and harvesting periods. The average labor occupancy in a 36-month period increased from $88.8 \%$ in Scenario $1 \mathrm{C}$ to $97 \%$ in Scenarios $2 \mathrm{C}$ and $3 \mathrm{C}$.

\subsection{Bodoquena Implementation}

The comparison of system annual costs showed a 16.2\% reduction between Scenarios 1B and 2B. Based on Scenario $3 \mathrm{C}$ results, there was a $14.9 \%$ decrease as compared to $1 \mathrm{C}$, which is mainly because the recommendation as to the number of pigs was not followed. 
In the Livestock Sector, Scenario 2B showed a $47 \%$ reduction in the number of beef cattle, which can be explained by the fact that Scenario 1B has a very high capacity, which is not compatible with pasture productivity, thus requiring supplementation; also, the workforce available was not enough for an optimal management to be obtained (Table 4). It would be feasible to reduce the herd and purchase the necessary beef to meet demand. This decision was validated by the team (3B) and a sale and revenue investment proposal for this sector was made. Thus, the number of horses could also be reduced (2B); however, there was a decision to keep the animals in the system (3B) for leisure use by students.

Table 4. Numbers of livestock and beehives in different scenarios

\begin{tabular}{llllll}
\hline Livestock & Scenario 1B & Scenario 2B & 1B/2B Variation (\%) & Scenario 3B & 2C/3B Variation (\%) \\
\hline Beef cattle: comercial herd & 981 & 519 & -47.1 & 519 & 0.0 \\
Horses and mules & 19 & 8 & -57.9 & 19 & +137.5 \\
Dairy cattle: total herd & 330 & 156 & -52.7 & 156 & 0.0 \\
Dairy cattle: lactating cows & 52 & 57 & +9.6 & 57 & 0.0 \\
Sheep & 21 & 49 & +133.3 & 49 & 0.0 \\
Swine & 87 & 131 & +50.6 & 100 & -23.7 \\
Broilers & $1 \times 1,000$ & $1 \times 1,000$ & 0.0 & $1 \times 1,000$ & 0.0 \\
Laying hens in production & 500 & 428 & -14.4 & 428 & 0.0 \\
Beehives & 20 & 4 & -80.0 & 20 & +400.0 \\
\hline
\end{tabular}

Note. Scenario 1C: base scenario; Scenario 2C: optimal solution; and Scenario 3C: after a year of decision making.

The dairy cattle herd could be reduced, which can be explained by a decrease in dry cows which represented $46 \%$ of the herd in Scenario 1B and would amount to $15 \%$ in 2B. Although there would be a $53 \%$ total herd reduction, the number of dairy cows would increase by $9.6 \%$ resulting in increased milk delivery to the Food Sector. The team considered it feasible and opted for 3B, including animal selection for surplus disposal.

As there was cattle herd reduction, other livestock could grow to optimize the workforce that remained constant. Sheep farming would increase from 13 to 20 dams in Scenario 2B as compared to 1B, whose implementation was approved (3B). Since pigs would add 5 dams (12 v. 19), the team estimated that would be a very high number and chose to keep 16 dams only (3B), acting to improve productivity without making use of 19 dams as suggested in 2B.

The broiler breeding activity should keep the same number animals for pedagogical restrictions; without these, broiler breeding would be impracticable and all poultry meat would be purchased. The production of laying hens proved to be feasible in the system with a recommendation to maintain this activity in $2 \mathrm{~B}$, though with reduction to adjust the minimum supply for the Food Sector. There was a recommendation to reduce beekeeping (2B), but the team eventually chose to maintain the 20 beehives that were already producing (3B), alleging that the impact on labor use would be small.

There are fewer activities in the agricultural sector on Bodoquena as compared to Canuanã. All Scenario 2B recommendationss were accepted by the team and validated for use in $3 \mathrm{~B}$ (Table 5). The vegetable garden area underwent a significant reduction and there was an increase in the fruit area. In 1B, despite an orchard area, the production process was inadequate, resulting in fruit loss because of harvest non-conformities due to lack of labor for such activity. Garden adjustments allowed to improve crop management and productivity gains are expected over the medium term. Another condition that contributed to vegetable garden reduction was pasture management, which was largely absent in $1 \mathrm{~B}$, since $2 \mathrm{~B}$ considered area adaptations and a constant work routine to maintain productivity and quality. Gardening kept the same area, being mandatory for the urbanized area. The pasture area needed to be reduced in view of new legislation that requires preservation area adjustments, with the loss of 100 hectares for reforestation. 
Table 5. Vegetable crops and plantation areas in different scenarios

\begin{tabular}{llllll}
\hline Crop & Scenario 1B & Scenario 2B & 1B/2B Variation $(\%)$ & Scenario 3B & 2B/3B Variation $(\%)$ \\
\hline Produce $\left(\mathrm{m}^{2}\right)$ & 30,000 & 5,070 & -83.1 & 5,070 & 0.0 \\
Fruit $\left(\mathrm{m}^{2}\right)$ & 77,113 & 97,832 & +26.9 & 97,832 & 0.0 \\
Garden $\left(\mathrm{m}^{2}\right)$ & 43,500 & 43,500 & 0.0 & 43,500 & 0.0 \\
Pasture (ha) & 550 & 450 & -18.2 & 450 & 0.0 \\
\hline
\end{tabular}

Note. Scenario 1: base scenario and Scenario 2: optimal solution.

Labor occupation percentage was over $98 \%$ throughout the year in the different scenarios, since there is no variation of annual crops as in Canuanã. The livestock peak is observed in broiler production and the agriculture peak when there is fruit harvest, because there is a reduction in the garden area to reconcile hours. The major restriction in this system is the hours devoted to the urbanized area, which represent nearly $50 \%$ of the total available time in the agricultural sector. It was found that including another employee to work in the garden and orchard would potentially reduce costs in over $2 \%$, since more food could be produced instead of being purchased.

As to milk processing there was a $10.3 \%$ delivery increase in $2 \mathrm{~B}(17,387 \mathrm{v} .15,600 \mathrm{~L} / \mathrm{month})$ due to an increase in the number of dairy cows. Thus, it was possible to produce and offer more dairy products in the canteen.

\section{Discussion}

\subsection{Decision-Making Based on an Optimal Scenario}

The scenarios created supported managers' decision-making and contributed to changes in the system practice. The complexity and sensitivity to market prices, which was also observed by Ashfield et al. (2013), could be represented. During five years of studies, several paradigms were broken by the analyses.

Several pieces of research have been conducted that have applied modeling in integrated systems and the continued use of this tool, as well as the need to train the staff involved from data collection to data analysis, has been a challenge (Groot et al., 2012).

Mellar et al. (1994) state that modeling allows to explore knowledge, investigate relationships, as well as formulate and test hypotheses. These have been observed in practice, and participants could make use of their knowledge and professional experience to suggest the creation of different situations in the farm-school reality. In this context, Johnson-Laird (1983) states that modeling allows the reconstruction of mental models, and Mellar et al. (1994) mention that, when confronted with non-conformities, people open to the new and seek different ways of understanding, thus facilitating the creation of alternative mental models. Along the formulation, it was realized that the contact with a multidisciplinary team of professionals through their multiple experiences in different but interelated areas favored integration, since a conceptual unity was necessary for the process; the greater understanding among professionals over the production process in which each operates was also relevant.

There was a dairy cattle technological change in Canuanã, where the extensive production system was abandoned and irrigated pasture was intensified. Such procedure agrees with studies that have shown the potentials of cattle raising intensification in pasture with the use of technologies related to soil, plant, animal and environment management to reduce costs by keeping animals in quality pastures (Fukumoto et al., 2010). In addition, it is emphasized that by reducing the number of dairy cows, there is also a reduction in the number of hours spent milking these animals, so these extra hours can be devoted to pasture management. For Gameiro et al. (2016), De Wit et al. (1980), Azevedo Filho and Neves (1982), the results obtained by applying the model indicated a creation strategy that should be adopted to optimize results. Like that of Tanure et al. (2013), the model used pasture as the main source of food, and could portray the complex relationships of the system.

Pig farming viability was identified on Bodoquena and Canuanã, both of which are self-sufficient in pork. The Brazilian swine sector is technified, and about $40 \%$ of the total herd is raised in integrated systems of large industries which hold specialized technologies that ensure competitiveness, with high volumes of processed products and higher added value (Willers et al., 2012). This viability was favored by the existence of local facilities and the logistic difficulties to purchase pork.

As to broilers, it was decided that production would only be carried out to meet class demands, as demonstrated in the optimized scenarios on the two farm-schools. The Brazilian poultry industry is technologically advanced, having farming and industrialization processes that allow high levels of conversion, precocity, productivity and 
survival by adopting vertical integration (Richetti \& Santos, 2000). The productivity gain in association with the poultry chain coordination makes Brazil one of the most efficient global producers, and because of the significant specialization of this activity, there has been a tendency to exclude small poultry farmers and less efficient producers from the production process (Zilli, 2003). Competing with vertically integrated systems using modern technologies and high genetics is not viable, so it was more practical to buy poultry on the market than produce it.

Except for rice in Canuanã, all the other crops have been or will be implemented in accordance with optimized Scenario indications on the two farm-schools. As to fruit and vegetables, one aspect to consider in the analysis is production specialization. There are several varieties being grown and these compete with structured markets using production technologies capable of generating competitive products at low prices. However, model results point to crop variability maintenance due to purchase difficulties on the market, especially in Canuanã, once freight has a significant impact on product price. These results differ from those obtained by Abdulkadri and Ajibefunb (1998), who suggested monoculture practice to maximize gross margin, showing that if production had been diversified, the results obtained would have been reduced.

Food processing and canteen planning is related to animal and plant production, and changes in sector variables have a direct impact on production, which can be measured by the proposed model. This issue was also discussed by Ahumada and Villalobos (2009) who included more than 60 articles in their review and showed various applications of linear programming in productive chain evaluation, encompassing both field and food processing production. These researchers pointed to the need to formulate models that can integrate production and distribution decisions, and the model proposed for the farm-boarding schools meets this item, since all the generated output is distributed to both food processing or canteen to feed the population. From the products purchased on the market or produced on farm-schools, varied menus for meals were created. It was possible to determine the amount of food to be offered in the canteen each month because of restrictions limiting servings and minimum and maximum monthly offer. Models to elaborate human diet have been studied since the $60 \mathrm{~s}$ and the biggest difficulty so far has been the inclusion of palatability in the model, since it is necessary to reconcile taste with nutritional needs (Namen \& Bornstein, 2004). It has been demonstrated that linear programming can be used to minimize food costs, as described by Araújo e Silva (2012) and Fracasso and Montezani (2005).

\subsection{Advances in the Model during the Process}

The model initially formulated allowed the development of various scenarios, as well as the interpretation and analysis of the global system for decision making (Tess \& Kolstad, 2000). However, in practice some conditions were identified as areas for improvement and were reviewed and reformulated before being implemented on the other farm-school.

Allowing the model to calculate animal diet based on their nutritional needs caused animal feed to have a different formula from that regularly used in the system, and this new diet was not adopted. The professionals continued using the previous formulation and with it, nutrition cost results did not come close to that calculated in Scenario 2C. Diet calculation as a sub-model is a difficulty that has been reported by other investigators, especially when it refers to pasture use, which has its own cycle and the equations can make incorrect estimates or require adjustment (Asfield et al., 2013; Bonesmo \& Randby, 2010). Thus, before the model was implemented on Bodoquena, meetings were held and a decision was reached to change the diet calculation. It was decided that a specific daily amount of concentrate would be assigned for each animal category, and that this would have a predefined formula. In the case of roughage feed, a minimum daily amount obtained using the options available for grazing, silage and hay would be set. The model can calculate a minimum cost diet for roughage feed only, since concentrate can not be changed. This change brought the scenario and practice outcomes close together. The adopted logic is not usually reported in literature, as working with formulas from nutritional requirement tables, as is the case of Gameiro et al. (2016) and Oliveira et al. (2010), is the rule.

In the Canuanã vegetable garden, production was divided into three groups and technicians were responsible for defining varieties to be produced through crop rotation. Therefore, productivity was estimated based on the average of varieties already grown. This decision was justified by the fact that vegetable production is a complex combinatorial optimization problem, as discussed by Santos (2009). It was thought that the insertion of this detail in the model would not be possible, as the technician responsible for the activity could plan based on the area appointed, with the possibility of considering seasonality of production and product purchase price fluctuations on the market. However, the need of the set to present all crops so that the result was closer to reality was identified. A survey was conducted on the two farm-schools to identify all crops, and afterwards equations were calculated that covered 10 different kinds of fruits and 47 kinds of vegetables, ie, an increase from 6 to 57 
varieties in set $\mathrm{c}$. This change resulted in more data to be collected, and this consequently demanded longer time; however, it facilitated decision making. This situation reflects the alegation of researchers that modeling seeks a balance between detail, precision and flexibility (Groot et al., 2012; Thornton \& Herrero, 2001).

On Bodoquena, because there were students and staff who did not live in the system, the need to change the quantities of meals was verified. Each diet food serving was multiplied by the number of days and number of people, whereas the Canuanã model was fixed. Along with this change it was necessary to determine the number of people on weekdays and weekends for all meals, which showed a $20 \%$ variation. In the canteen, the first model formulated to Canuanã considered the main food items of the population meals to generate demand for food. Thus, the costs obtained because of the objective function represented the entire food processing payroll staff and food sector as well as all purchased food. The inclusion of purchased food for the population i.e., food that could not be produced on the farm-school (beans, pasta, etc.) did not have to be accounted for, since formulating menus at minimal cost was not a goal. Moreover, canteen data revealed that fat and gristle were removed after the slaughter of animals and the chilled carcass obtention, generating a loss that was not converted into meat servings. To map this loss and simulate the impact of total fat removal from the carcass, a restaurant loss parameter was inserted into the model. Thus, each slaughtered animal had its weight converted into carcass, from which the restaurant loss was discounted, and then this amount was divided into individual servings to make up lunch and dinner.

\subsection{Innovations}

The formulated model showed an optimized scenario which extended the managers' analysis horizon and allowed safer decision making. This situation has also been reported by other researchers who have developed models and conducted practical applications (Groot et al., 2012; Rossing et al., 2007; Janssen \& Ittersum, 2007). Recently, several models have been formulated and applied around the world to assess organic systems (Acs, 2007), grain yield (Biagio et al., 2007), crop sequencing (2008), integration activities (Zingore et al., 2009), crop rotation (Santos, 2009), as well as crop selection and water use (Reeling et al., 2012). However, these studies did not focus on a model that could represent a complete system involving production and product conversion within the system for self-supply and keeping item variability to cater to the learning process.

As to animal production, it must be emphasized that the $X A P$ variable $(a, t)$ gives the number of animals per category, which is a differential in this model. It calculates the number of animals in the main category (matrix) for each species and from this the amounts for the remaining categories are generated, observing the generated ratio from zootechnical indices to maintain herd stability. This has a direct impact on the collection of data to make up model parameters and requires a differentiated organization from that adopted in production system routine monitoring, which normally controls indicators per batch of animals. It is necessary to identify values related to a production unit rather than the activity as a whole, which presents comprehension difficulties, demanding staff training efforts. Still referring to animal production, herd dynamics was designed in a similar way to that described by Gameiro et al. (2016) and Barros (2012), taking age into account, differing from Parsons et al. (2012), who also considered a stable herd but attributed animal category according to weight.

Agroindustrial production planning aimed to animal and plant production was not only possible but allowed variability. The strategy adopted by the model of considering diet variation needs by setting minimum and maximum days per month (frequency) on which each food may appear in the menu allowed respecting both population preferences and cultural characteristics of food, and has not been reported in literature.

A pivotal point in the model formulation was to establish the need for practical class resources that would suit all students. Studies showing criteria to define the number of animals per category, vegetable cultivation area and quantity of products in food processing to be produced by students have not been found. Therefore, studies within the farm-school premises based on teachers' records were developed so as to prepare the pedagogical restrictions included in the model.

\section{Conclusions}

The model proved to be efficient in representing the farm-boarding school system and contributed significantly to production planning to optimize the use of available resources. It was found that the modeling process enabled the identification of relationships among production processes and promoted the integration of the work team from data collection to scenario analysis, which was facilitated because there was a greater understanding of the system as a whole, expanding evaluation horizons beyond the sector in which it operated, eventually leading to conflict reduction. 
The system's complexity hampers dialogue between the farm-boarding school team and managers. From the modeling process and the standardization of data and generated results, there was a greater safety margin to present investment proposals and analyzes, accelerating the decision-making process, which was a positive addition to the system.

The model used in this research represents the farm-boarding school system and has the potential to be applied to other institutions aiming at the rational use of resources, thus contributing to the work of managers and technicians, as well to the teaching and learning processes of teachers and students.

\section{References}

Abdulkadri, O., \& Ajibefunb, I. A. (1998). Developing alternative farm plans for cropping system decision making. Agricultural Systems, 56, 431-442. https://doi.org/10.1016/S0308-521X(97)00058-9

Acs, S., Berentsen, P. B. M., \& Huirne, R. B. M. (2007). Conversion to organic arable farming in the Netherlands: A dynamic linear programming analysis. Agricultural Systems, 94, 405-415. https://doi.org/ 10.1016/j.agsy.2006.11.002

Ahumada, O., \& Villalobos, J. R. (2009). Application of planning models in the agri-food supply chain: A review. European Journal of Operational Research, 195, 1-20. https://doi.org/10.1016/j.ejor.2008.02.014

Araújo, V. M. B. M., \& Silva, L. F. R. (2012). Mathematical Modeling Applied to Food diets and study of obesity. Electronic Journal of Education and Science, 2, 30-43.

Ashfield, A., Crosson, P., \& Wallace, M. (2013). Simulation modelling of temperate grassland based dairy calf to beef production systems. Agricultural Systems, 115, 41-50. https://doi.org/10.1016/j.agsy.2012.10.001

Azevedo Filho, A. J. B. V., \& Neves, E. M. (1982). The use of mathematical programming in investment analysis in beef cattle: intensive techniques vs. capital market. Paper presented at the Latin American Congress of Operations Research and Systems Engineering, Rio de Janeiro.

Barros, C. S. (2012). Use of linear programming as a pedagogical and management tool in agricultural production: the case of school - farm Canuanã (Unpublished doctoral dissertation). Faculdade de Medicina Veterinária e Zootecnia da Universidade de São Paulo, Pirassununga, Brazil.

Biagio, M. A., Abe, E. N., \& Turnes, O. (2007). Modelo para planejamento de produção de grãos em fazenda familiar: Cenários sócio-econômicos e financeiros. Operational Research, 27, 377-405. https://doi.org/ 10.1590/s0101-74382007000300001

Bonesmo, H., \& Randby, A. T. (2010). The effect of silage enegy concentration and price on finishing for young dairy bulls. Grass Forage Science, 66, 78-87. https://doi.org/10.1111/j.1365-2494.2010.00765.x

Conceição, J. T. (2010). Boarding History: Federal agricultural education (1934-1967). History Magazine, 2, 80-99.

De Wit, C. T., Van Keulen, H., Seligman, N. G., \& Spharim, I. (1988). Application of interactive multiple goal programming techniques for analysis and planning of regional agricultural development. Agricultural Systems, 26, 211-230. https://doi.org/10.1016/0308-521X(88)90012-1

Fracasso, P. T., \& Montezani, E. (2005). Minimizing costs for collective meals of USP-SP. Paper presented at the Congress National Applied and Computational Mathematics, São Carlos, Brazil.

Franco, M. P. (1994). High school: Challenges and reflections. Campinas, SP. Papirus.

Fukumoto, N. M., Damasceno, J. C., Deresz, F., Martins, C. E., Cóser, A. C., \& Santos, G. T. (2010). Milk yield and composition, feed intake and stocking rate of crossbread cows in tropical grasses managed in a rotational grazing system. Revista Brasileira de Zootecnia, 39, 1548-1557. https://doi.org/10.1590/ S1516-35982010000700022

Gameiro, A. H., Rocco, C. D., \& Caixeta-Filho, J. V. (2016). Linear Programming in the economic estimate of livestock-crop integration: Application to a Brazilian dairy farm. Revista Brasileira de Zootecnia, 45(4), 181-189. https://doi.org/10.1590/S1806-92902016000400006

Goffman, E. (1974). Asylums, prisons and convents. São Paulo: Perspectiva.

Groot, J. C. J., Oomen, G. J. M., \& Rossing, W. A. H. (2012). Multi-objective optimization and design of farming systems. Agricultural Systems, 110, 63-77. https://doi.org/10.1016/j.agsy.2012.03.012

Janssen, S., \& Ittersun, M. K. (2007). Assessing farm innovations and responses to policies: A review of bio-economic farm models. Agricultural Systems, 94, 622-636. https://doi.org/10.1016/j.agsy.2007.03.001 
Johnson-Laird, P. N. (1983). Mental models: Towards a cognitive science of language, inference and consciousness. Cambridge, MA: Harvard University Press.

Marques, P. V, \& Love, H. G. (1993). Cooperative school in agricultural technical schools. Scientia Agricola, 50, 509-513. https://doi.org/10.1590/S0103-90161993000300028

Mellar, H., Bliss, J., Boohan, R., Ogborn, J., \& Tompsett, C. (Eds.). (1994). Learning with Artificial Worlds: Computer Based Modelling in the Curriculum (1st ed.). London: The Falmer Press.

Mont'alvão, C. R. F. (2008). Work and education in the technical course in farming of CEFET-Januária-MG: breaking teaching models (Unpublished master's thesis). Universidade Federal Rural do Rio de Janeiro, Seropédica, Rio de Janeiro, Brazil.

Namen, A. A., \& Bornstein, C. T. (2004). Uma ferramenta para avaliação de resultados de diversos modelos de otimização de dietas. Pesquisa Operacional, 24, 445-465. https://doi.org/10.1590/S0101-743820040 00300007

Oliveira, J. E. G., Soares, J. B., Barioni, L. G., Leite, G. G., Braga, A. C., \& Menezes, M. E. (2010). Optimized feed planning for grazing horse production systems. Revista Brasleira de Zootecnia, 39, 932-940. https://doi.org/10.1590/S1516-35982010000400030

Parsons, D., Nicholson, C. F., Blake, R. W., Ketterings, Q. M., Ramírez-Aviles, L., Fox, D. G., ... Cherney, J. H. (2011). Development and evaluation of an integrated simulation model for assessing smallholder crop-livestock production in Yucatán, Mexico. Agricultural Systems, 104, 1-12. https://doi.org/10.1016/ j.agsy.2010.07.006

Reeling, C. J., Weir, A. E., Swinton, S. M., \& Hayes, R. C. (2012). A comparative breakeven net return threshold to guide development of conservation technologies with application to perennial wheat. Paper presented at the Agricultural \& Applied Economics Association's 2012, Annual meeting, Washington.

Richetti, A., \& Santos, A. C. (2000). The integrated broiler production in Minas Gerais: an analysis from the perspective of ECT. Rural and Agribusiness Organizations, 2, 34-43.

Rossing, W. A. H., Zander, P., Josien, E., Groot, J. C. J., Meyer, B. C., \& Knierim, A. (2007). Integrative modelling approaches for analysis of impact of multifunctional agriculture: A review for France, Germany and The Netherlands. Agriculture, Ecosystems \& Environment, 120, 41-57. https://doi.org/10.1016/ j.agee.2006.05.031

Santos, L. M. R. (2009). Crop rotation schedule: Models and solution methods (Unpublished doctoral dissertation). Instituto de Ciências Matemáticas e de Computação, Universidade de São Paulo, São Carlos, São Paulo, Brazil.

Tanure, S., Nabinger, C., \& Becker, J. L. (2013). Bioeconomic model of decision support system for farm management. Part I: Systemic conceptual modeling. Agricultural Systems, 115, 104-116. https://doi.org/ 10.1016/j.agsy.2012.08.008

Tess, M. W., \& Kolstad, B. W. (2000). Simulation of cow-calf production systems in a range environment: I. Model development. Journal of Animal Science, 78, 1159-1169. https://doi.org/10.2527/2000.7851159x

Thornton, P. K., \& Herrero, M. (2010). Potential for reduced methane and carbon dioxide emissions from livestock and pasture management in the tropics. Proceedings of the National Academy of Sciences, 107, 19627-19632. https://doi.org/10.1073/pnas.0912890107

Willers, E. M., Alves, L. R., Staduto, J. A. R., \& Germann, C. (2012). Analyzing the concentration of creative industries, slaughter and pork meat processing in western Parana. Revista de Administração, Contabilidade e Economia, 11, 103-130.

Zilli, J. B. (2003). The determining factors for the economic efficiency of broiler producers: A stochastic analysis (Unpublished master's thesis). Escola Superior de Agricultura Luiz de Queiroz, Piracicaba, São Paulo, Brazil.

Zingore, S., González-Estrada, E., Delve, R. J., Herrero, M., Dimes, J. P., \& Giller, K. E. (2009). An integrated evaluation of strategies for enhancing productivity and profitability of resource-constrained smallholder farms in Zimbabwe. Agricultural Systems, 101, 57-68. https://doi.org/10.1016/j.agsy.2009.03.003 


\section{Copyrights}

Copyright for this article is retained by the author(s), with first publication rights granted to the journal.

This is an open-access article distributed under the terms and conditions of the Creative Commons Attribution license (http://creativecommons.org/licenses/by/4.0/). 